\title{
Isobutanol tolerance in Ralstoniaeutropha
}

\author{
Amanda Bernardi ${ }^{1,2^{*}}$, Cláudia Gai ${ }^{1}$, Jingnan Lu ${ }^{3}$, Christopher Brigham ${ }^{1,4}$, Anthony Sinskey $^{5}$ \\ From 5th Congress of the Brazilian Biotechnology Society (SBBIOTEC) \\ Florianópolis, Brazil. 10-14 November 2013
}

\section{Background}

Ralstonia eutropha is bacterium known to naturally produce polyhydroxybutyrate (PHB) as carbon storage during nutrient starvation. Previously studies [1] showed that it is possible through the incorporation of an engineered biosynthetic pathway, to redirect carbon flux from PHB to the production of Isobutanol (IBT), a biofuel largely studied to replace the current fossil fuels in existing automobile engines. However $R$. eutropha, is unable to grow in the presence of IBT at concentrations above $0.2 \%\left(\mathrm{v} \mathrm{v}^{-1}\right)$ which decreases its potential for industrial scale production. In order to minimize toxicity to the cells, we studied IBT tolerance to develop an IBT tolerant strain. We selected tolerant strains through experimental evolution and we confirmed the existence of mutations in 2 genes of $R$. eutropha evolved strains, the homologues of acrA and acrA6 in Escherichia coli, which were previously described as being related to IBT tolerance [2,3]. Those 2 genes were deleted from the wild type and engineered IBT-producing strains in order to evaluate improvement in IBT tolerance.

\section{Methods}

R. eutropha strains were cultivated at $30^{\circ} \mathrm{C}$ in rich and minimal media using fructose or IBT as carbon source. Experimental evolution was performed by sequential transfer method, adapted from previously work in alcohol tolerance $[2,3]$. For the deletion of the target genes, standard procedures were used as previously described [4] and all plasmids used for gene knock-out were constructed using Gibson Assembly technique. Isobutanol tolerance was compared by growth of strains in different IBT concentration, and by survival colony forming units (CFU $\mathrm{ml}^{-1}$ ) counting after exposition to elevated IBT concentration. Isobutanol consumption was tested by growth using IBT as exclusive carbon source. Culture aliquots were taken at different time points and IBT was extracted in order to evaluate IBT production.

\section{Results and conclusions}

The effects of deletions were assessed separately and simultaneously, through IBT tolerance, consumption and production assays which showed that deletions did not significantly improve growth in the presence of IBT; however they increased the survival number of $\mathrm{CFU} \mathrm{m}{ }^{-1}$ in the presence of elevated concentrations of IBT. Moreover, an IBT producer strain with the acrA deletion was able to produce 3 times more IBT than its parental strain, which could potentially be associated with enhanced survival rate at high IBT concentration. Studies showed that the presence of extracellular IBT causes quinone depletion, reducing activity for enzymes that utilize it for their electron-carrier capability [5]. In E. coli, deletion of AcrAB-TolC units increased IBT tolerance by reducing this quinone depletion [3]. Our study has shown that this mechanism might be similar in $R$. eutropha response to IBT stress.

\footnotetext{
Acknowledgements

This project is funded by the Advanced Research Projects Agency-Energy (ARPA-E). My thanks to Conselho Nacional de Desenvolvimento Científico e Tecnológico (CNPQ) for financing my stay in the United States through the Science Without Borders program.

\begin{abstract}
Authors' details Massachusetts Avenue, Cambridge, MA 02139, USA. ${ }^{2}$ Universidade Federal Technology, 77 Massachusetts Avenue, Cambridge, MA 02139, USA. Old Westport Road, North Dartmouth, MA 02747, USA. ${ }^{5}$ Department of Biology, Division of Health Sciences and Technology, Engineering Systems Division, Massachusetts Institute of Technology, 77 Massachusetts Avenue, Cambridge, MA 02139, USA.
\end{abstract}

${ }^{1}$ Department of Biology, Massachusetts Institute of Technology, 77 de Alfenas, MG, Brazil. ${ }^{3}$ Department of Chemistry, Massachusetts Institute of

${ }^{4}$ Department of Bioengineering, University of Massachusetts Dartmouth, 285
} 


\section{References}

1. Lu J, Brigham CJ, Gai CS, Sinskey AJ: Studies on the production of branched-chain alcohols in engineered Ralstonia eutropha. Appl Microbiol Biotech 2012, 96:283-297, doi: 10.1007/s00253-012-4320-9.

2. Minty JJ, Lesnefsky AA, Lin F, Chen Y, Zaroff TA, Veloso AB, Xie B, McConnell CA, Ward RJ, Schwartz DR, Rouillard JM, Gao Y, Gulari E, Lin XN: Evolution combined with genomic study elucidates genetic bases of isobutanol tolerance in Escherichia coli. Microbial Cell Factories 2011, 25:18-56, doi: 10.1186/1475-2859-10-18.

3. Atsumi S, Wu TY, Machado IM, Huang WC, Chen PY, Pellegrini M, Liao JC: Evolution, genomic analysis, and reconstruction of isobutanol tolerance in Escherichia coli. Molecular Systems Biology 2010, 21:6:499, doi: 10.1038/ msb.2010.98.

4. Quandt J, Hynes MF: Versatile suicide vectors which allow direct selection for gene replacement in gram-negative bacteria. Gene 1993 15:15-21.

5. Brynildsen MP, Liao JC: An integrated network approach identifies the isobutanol response network of Escherichia coli. Molecular Systems Biology 2009, 5:277, doi: 10.1038/msb.2009.34.

doi:10.1186/1753-6561-8-S4-P232

Cite this article as: Bernardi et al:: Isobutanol tolerance in

Ralstoniaeutropha. BMC Proceedings 2014 8(Suppl 4):P232.

\section{Submit your next manuscript to BioMed Central} and take full advantage of:

- Convenient online submission

- Thorough peer review

- No space constraints or color figure charges

- Immediate publication on acceptance

- Inclusion in PubMed, CAS, Scopus and Google Scholar

- Research which is freely available for redistribution

Submit your manuscript at www.biomedcentral.com/submit
Ciomed Central 